\title{
Vanishing calcified thoracic disc herniation
}

\author{
Luis Salazar, ${ }^{1}$ David J Wallace, ${ }^{2}$ Ramesh Grandhi, ${ }^{3}$ Donald P Atkins ${ }^{2}$
}

'Long School of Medicine, University of Texas Health Science Center at San Antonio, San Antonio, Texas, USA ${ }^{2}$ Department of Neurosurgery, University of Texas Health Science Center at San Antonio, San Antonio, Texas, USA ${ }^{3}$ Department of Neurosurgery, University of Utah Health Sciences Center, Salt Lake City, Utah, USA

\section{Correspondence to} Dr Ramesh Grandhi,

ramesh.grandhi@hsc.utah.edu

Accepted 27 April 2019

\section{DESCRIPTION}

A 66-year-old man with a history of two L4-L5 minimally invasive tubular approaches for microdiscectomy and an L5-S1 anterior lumbar interbody fusion returned to the clinic after 1 year for thoracic and left flank pain. The pain began a few weeks before presentation. Pain was described as sharp and stretching across his mid-back without radiation to the front. CT scan of the abdomen revealed a calcified lesion contiguous with the disc space protruding into the epidural space at T10T11 (figure 1). MRI scan of the thoracic spine eliminated suspicion for an epidural abscess and haematoma (figure 2). Interestingly, a plain radiograph from 2 years prior demonstrated calcifications within the T10-11 disc space.

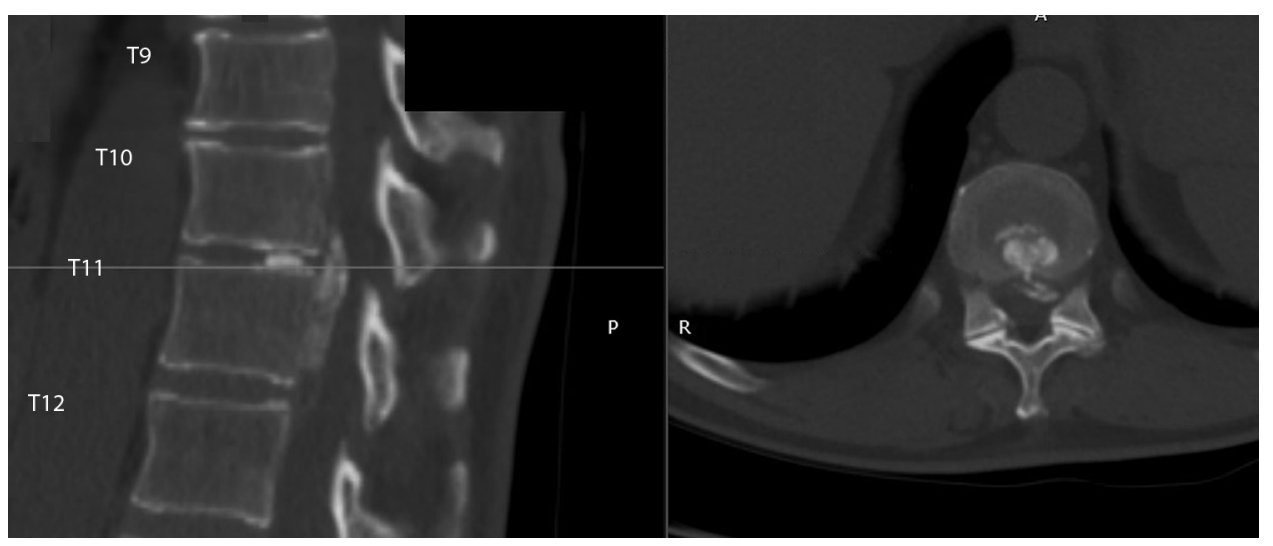

Figure 1 CT scan revealing calcified lesion at T10-T11.

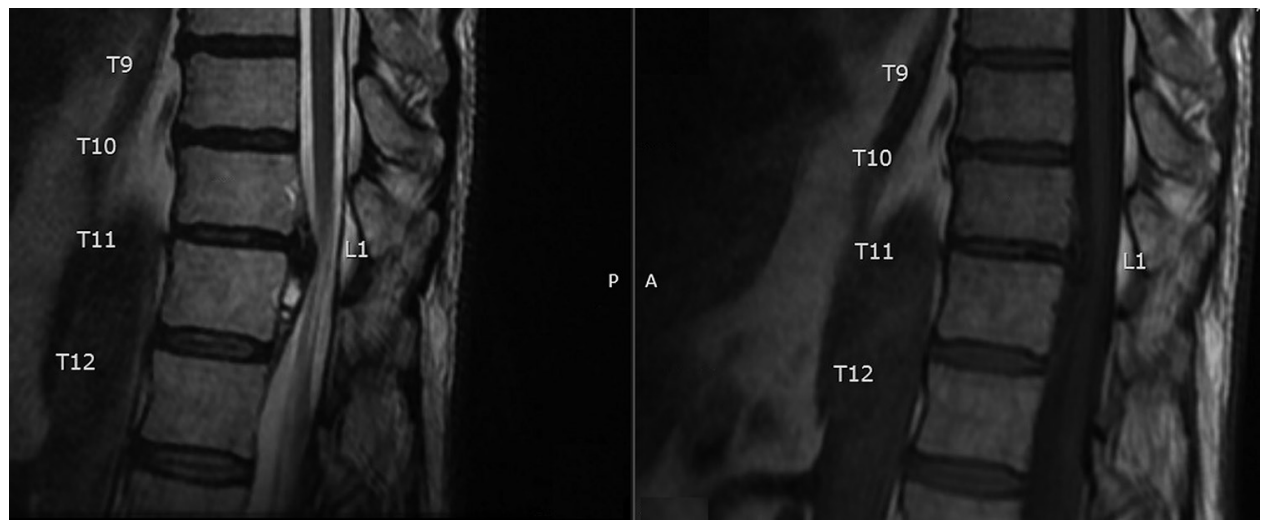

Figure 2 MRI scan of the thoracic spine eliminating suspicion for spinal epidural abscess.

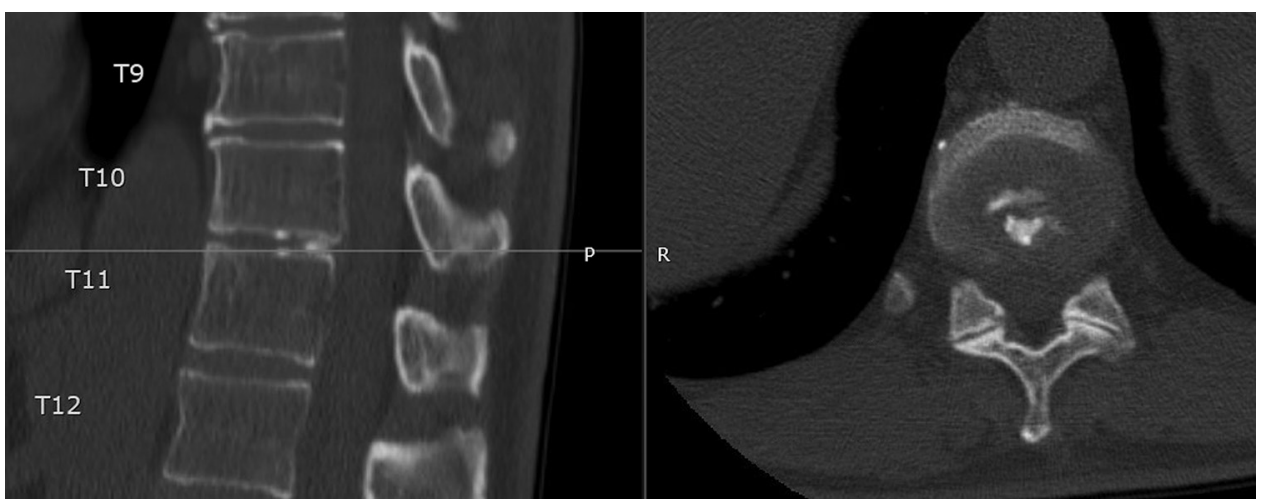

Figure 3 CT scan revealing spontaneous resolution of lesion at T10-T11.

(c) BMJ Publishing Group Limited 2019. No commercial re-use. See rights and permissions. Published by BMJ.

To cite: Salazar $\mathrm{L}$, Wallace DJ, Grandhi R, et al. BMJ Case Rep 2019:12:e228799 doi:10.1136/bcr-2018228799 


\section{Learning points}

Calcified disc herniations may resolve spontaneously with conservative management.

- The differential diagnosis for a ventral epidural mass should include disc herniation, epidural haematoma, osteodiscitis with abscess, and benign intra-axial neoplasm (ie, meningioma, schwannoma).

The patient denied systemic signs of illness, and laboratory markers for infection were low. The patient also denied any recent injections, new neurological deficits, myelopathic symptoms or trauma. He had no risk factors for calcified discs (ie, metabolic disorders), osteodiscitis or epidural haematoma. The patient failed conservative pain management with medication alone (ibuprofen, gabapentin and methylprednisolone dose pack) at a 6-week follow-up. The patient subsequently received a thoracic epidural steroid injection (ESI) that led to symptom resolution. On 6-month follow-up, the patient was symptom free, and a CT scan revealed radiographic resolution of the epidural calcification (figure 3 ).

This case most likely represents a calcified disc herniation with spontaneous resolution. Disc reabsorption is likely to be the natural history of this entity, with the ESI providing symptomatic relief while healing is occurring. ${ }^{12}$

Contributors LS and DPA were involved in drafting of the case report. DJW and RG were involved in editing of the case report.

Funding The authors have not declared a specific grant for this research from any funding agency in the public, commercial or not-for-profit sectors.

Competing interests None declared.

Patient consent for publication Obtained.

Provenance and peer review Not commissioned; externally peer reviewed.

\section{REFERENCES}

1 Hochman MS, Pena C, Ramirez R. Calcified herniated thoracic disc diagnosed by computerized tomography: case report. J Neurosurg 1980;52:722-3.

2. Harshavardhana NS, Panvica TP, Pinto MR. Spontaneous regression of a large symptomatic calcified central thoracic disc herniation: a case report with a review of the literature. J Head Neck Spine Surg 2017;1:555565.

Copyright 2019 BMJ Publishing Group. All rights reserved. For permission to reuse any of this content visit

https://www.bmj.com/company/products-services/rights-and-licensing/permissions/

BMJ Case Report Fellows may re-use this article for personal use and teaching without any further permission.

Become a Fellow of BMJ Case Reports today and you can:

- Submit as many cases as you like

- Enjoy fast sympathetic peer review and rapid publication of accepted articles

- Access all the published articles

- Re-use any of the published material for personal use and teaching without further permission

For information on Institutional Fellowships contact consortiasales@bmjgroup.com

Visit casereports.bmj.com for more articles like this and to become a Fellow 